\title{
VIRULENCE OF STREPTOCOCCUS FAECIUM ISOLATED FROM FRESHWATER CRAYFISH, PROCAMBARUS CLARKII, TO NILE TILAPIA" OREOCHROMIS NILOTICUS
}

\author{
AYA GALAL SAAD EL-DEEN \\ Animal Health Research Institute, Assiut Regional Laboratory. \\ Email: aya9galal@gmail.com
}

\begin{tabular}{|c|c|}
\hline & ABSTRACT \\
\hline Received at: $21 / 8 / 2013$ & $\begin{array}{l}\text { The study was carried on } 100 \text { Procambarus Clarkii collected from the small tributaries } \\
\text { of El-Ibrahemia canal, Assiut city. The clinical signs and postmortem lesions of red } \\
\text { swamp crayfish were recorded. P. clarkii were subjected to bacteriological } \\
\text { examinations. The isolated bacteria were identified as Streptococcus faecium. The } \\
\text { percentage of infection was } 36 \% \text { among the examined crayfish. Isolates were isolated } \\
\text { from haemolymph, hepatopancrease and brain. Experimental infection was successful } \\
\text { through intraperitoneal injection of Nile tilapia. The clinical signs were darkening in } \\
\text { colour, haemoragic skin and fin. The fish showed gasping air, detachment of scales } \\
\text { and skin erosion and ulcer. The common postmortem lesions were congestion of } \\
\text { internal organs. The aforementioned bacterial isolate was successfully re-isolated from } \\
\text { experimentally infected fish. }\end{array}$ \\
\hline
\end{tabular}

Key words: Streptococcus faecium, Nile tilapia, freshwater crayfish, hetero-species susceptibility.

\section{INTRODUCTION}

Nile tilapia, Oreochromis niloticus is the most cultivated freshwater fish species due to its peculiar characteristics such as rusticity, resistance, productivity, adaptability to a wide range of environmental conditions and ability to grow and reproduce in captivity. As a result, these fishes have become excellent candidates for aquaculture, specially in tropical and subtropical regions and the number of farms has been increasing annually all over the world (Newaj- fyzul et al., 2008).

Bacterial diseases induce colossal economic losses in both wild and cultured fish (Abowei and Briyai 2011). Streptococcal infection of fish is considered a re-emerging pathology affecting a variety of wild and cultured fish throughout the world (Romalde and Toranzo, 2002). Streptococcosis affects Oreochromis spp. as well as grey mullets (Mugil cephalus and Liza ramada) and silver carp, but not common carp (Hubbert, 1989). The major identifying feature of Streptococcus is that they are Gram-positive, aerobic and the bacterial cells appear more spherical or oval (coccus) in shape, grouped in pairs or short chains (Domenech et al., 1996). Bacteriological data showed that streptococcosis is caused by various species; including Streptococcus faecalis, Streptococcus facieum \& Streptococcus agalaciae and unclassified Streptococcus species (Kusuda and Salati, 1999).

Procambarus clarkii is considered the most important crayfish of the 400 species known in the world, and has been successfully introduced to all countries.
(Masser and Rouse 1997). In Egypt however, the present stock of crayfish was found to be promising although average annual yield under exploitation was estimated to be about 4.6 tons only (Emam and Khalil, 1995).

This study was done to investigate the existence of streptococcus spp. in red swamp crayfish in Assiut. As well as the pathogenicity of the strain recovered from red swamp crayfish to Nile tilapia.

\section{MATERIALS and METHODS}

\section{Red swamp crayfish:}

A total number of 100 alive red swamp crayfish, Procambarus clarkii, were collected from the small tributaries of El-Ibrahemia canal, Assiut city. The body weight ranged from 10 to $20 \mathrm{~g}$ with total length of 9-14 cm. They were transported to the Aquatic Animals Diagnostic Laboratory, Faculty of Veterinary Medicine, Assiut University, where clinical and bacteriological examinations were conducted (Melba et al., 2001).

\section{Nile tilapia:}

A total number of 50 apparently healthy $\mathrm{O}$. niloticus with an average body weight of $50 \pm 10 \mathrm{gm}$ were collected from a private fish farm. The collected fish were transported to the laboratory as soon as possible. The fish were kept in well aerator glass aquaria under the laboratory conditions for two weeks for acclimated .Random specimens from fish were taken for disease examination to ensure that fish were healthy. 


\section{Bacteriological isolation and identification:}

Bacteria were isolated from hepatopancrease, brain and hemolymph of the collected crayfish. Samples of hepatopancrease, brain and hemolymph were bacteriologically examined by inoculation on brain heart infusion agar (BHI) (Lab-M) supplemented with $0.2 \mathrm{~g} / \mathrm{L}$ sodium azide, blood agar (biolife) supplemented with $5 \%$ sterile sheep's blood and incubated at $37^{\circ} \mathrm{C}$ for $24-48$ hours. Suspected colonies were purified and kept in refrigerator at $4{ }^{\circ} \mathrm{C}$ for further biochemical identification. Pure cultures of the isolates were identified based on phenotypic and biochemical characters and enzyme activities as described (Hardie, 2001).

\section{Pathogenicity of streptococcus faecium to O. niloticus:}

\section{Bacterial strains:}

Bacterial isolates from hepatopancrease of red swamp crayfish were identified as Streptococcus faecium was passed three times through red swamp crayfish via haemolymph injection and used for determination of pathogenicity. Streptococcus isolate was grown on $\mathrm{BHI}$ agar and suspended in sterile distilled water to use for experimental infection.

\section{Bacterial counts and dilutions:}

A preliminary growth curve study was conducted to determine counts of colony forming units (CFU) of Streptococcus faecium in BHI broth at various growth phases using standard plate count method (ElKamel and Thune, 2003).

\section{Experimental challenge to $O$. niloticus:}

Recovered streptococcus faecium was tested for their pathogenicity in O. niloticus as means of evaluating their virulence profiles. A total number of 45 apparently healthy Nile tilapia were divided in to 3 groups, each of 15 fish, each group in three replicates. The fish in the first group were I/P injected with 0.33 $\mathrm{ml}$ of a bacterial suspension $0.3 \times 10^{8} \mathrm{cfu} / \mathrm{ml}(\mathrm{saad}$ Eldeen and EL-Nisr 2011) (the experimental strain used for experimental inoculation was Nacl-tolerant), while fish in the second group injected with $033 \mathrm{ml}$ of sterile saline and the third group remained uninjected. The whole experiment was repeated 3 times.

Experiments were monitored by continuous examination for clinical signs, lesions, mortalities and bacterial re-isolation throughout 15 days.

\section{RESULT}

1-Clinical and bacteriological examination of red swamp crayfish:

Naturally infected P. clarkii with Streptococcus faecium revealed no gross or postmortem typical lesions of streptococcal infection, but 7 crayfish showed black spot on the back of the abdomen. Also, eleven crayfish showed necrosis at telsons and uropods. The remaining crayfish appeared to be clinically healthy.

Pure cultures of isolated bacteria were successfully done from haemolymph, brain and hepatopancrease of naturally infected $P$. clarkii. The isolates were identical biochemical characteristics suggesting that they were all the same or closely related species. Bacteriological examination of naturally infected red swamp crayfish resulted in the identification of 56 streptococcus faecium from 36 P. clarkii out of 100 examined crayfish with a percent of $36 \%$. Streptococcus faecium was isolated from Haemolymph, haepatopancrease and brain of red swamp crayfish with percentage of $25,57.14$, and $17.86 \%$ respectively.

Streptococcus faecium was recovered from P. clarkii was gram positive cocci, arranged in pairs and short chain, non motile. It grows at brain heart infusion agar with sodium azide giving pen head, dull creamy, circular, translucent, slightly convex colonies. On blood agar colonies were pale grey rounded colonies with zone of $\alpha$-haemolysis (greenish coloration). The biochemical patterns of the recovered isolates are summarized in Table 1.

\section{2-Experimental infection:}

The experimental inoculation of St. faecium in $O$. niloticus induced $33.33 \%$ mortalities within 15 days post injection. Four infected fish were darkening in colour. petechial haemorrhage in the mouth region and on the fins were noticed in 6 of fish (Fig. 1). Detachment of scales and skin erosions and ulcers were observed in 2 cases. The ulcers were usually shallow (Fig. 2). Three fish showed exophthalmia accompanied by haemorrhage of the eyes. Fin and tail rot were observed in 4 fish. Necropsy findings showed, liver was pale in colour in 6 experimental infected fish. Spleen, kidney and gills were congested in 7 fish. Gall bladder was distended with bile (fig. 3). Injected streptococcus species was successfully reisolated from liver, kidney and spleen of the injected fishes. No mortality occurred in control fish and the bacterium was not isolated from any organ. 
$\underline{\text { Assiut Vet. Med. J. Vol. } 59 \text { No. } 159 \text { October } 2013}$

Table 1: Cultural and biochemical characters of the isolated bacteria $(n=56)$ :

\begin{tabular}{|c|c|}
\hline Biochemical test & Response \\
\hline Gram-stain & $\mathrm{G}+\mathrm{ve}$ Cocci in pair or short chain \\
\hline Motility & - \\
\hline Oxidase & - \\
\hline Catalase & - \\
\hline Growth on MacConkey agar & - \\
\hline $10^{\circ} \mathrm{C}$ & + \\
\hline $37^{\circ} \mathrm{C}$ & + \\
\hline $45^{\circ} \mathrm{C}$ & + \\
\hline $6.5 \% \mathrm{NaCl}$ & $48 / 56$ \\
\hline Vogus proskauer & + \\
\hline Indole & - \\
\hline Citrate utilization & - \\
\hline $\begin{array}{cc}\text { TSI } & \mathrm{H}_{2} \mathrm{~S} \\
& \text { gas } \\
& \text { reaction }\end{array}$ & $\begin{array}{c}- \\
- \\
\mathrm{A} / \mathrm{A}\end{array}$ \\
\hline Urease & - \\
\hline Orgnine decarboxylase & + \\
\hline Ornithine decarboxylase & + \\
\hline \multicolumn{2}{|l|}{ Acid produce from: } \\
\hline Glucose & + \\
\hline Raffinose & + \\
\hline Sucrose & + \\
\hline Lactose & + \\
\hline Arabinose & + \\
\hline Mannitol & + \\
\hline Sorbitol & - \\
\hline
\end{tabular}



Fig. 1: Nile tilapia, experimentaly injected with Streptococcus faecium isolated from $P$. clarkii showing petechial haemorrage in mouth region and fin 


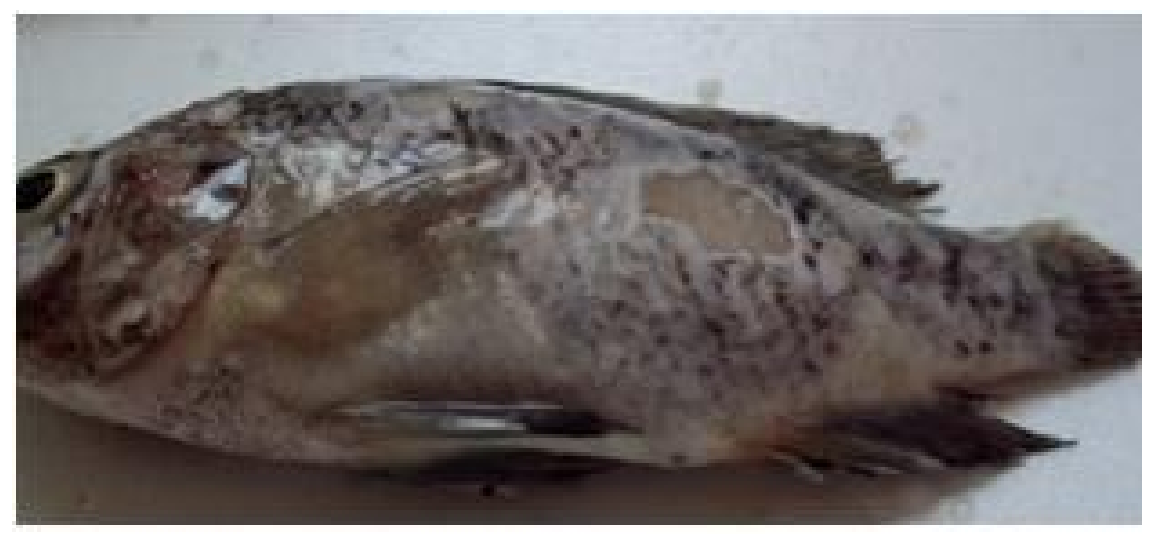

Fig. 2: Nile tilapia, experimentaly injected with Streptococcus faecium isolated from P. clarkii showing detachment scales and skin ulceration

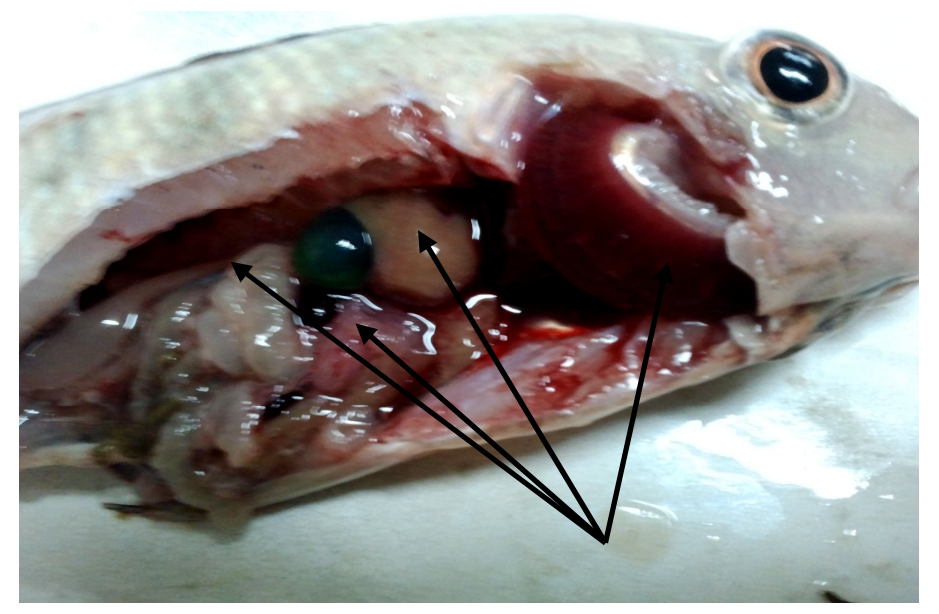

Fig.3: Nile tilapia, experimentaly injected with Streptococcus faecium isolated from P. clarkii showing congested spleen, kidney, gills and pale liver

\section{DISCUSSION}

Streptococcus species Causes a major disease problem in cultured tilapia and reported to cause high economic losses in both wild and cultured fish (Domench et al., 1996).

Naturally infected P. clarkii with Streptococcus faecium did not show typical gross and postmortem lesions of Streptococcus infection. Edgerton et al. (2002) reported that Crayfish with asymptomatic bacteremia typically exhibit no gross or histopathological signs of disease. The condition is diagnosed by standard bacterial culture and identification techniques for aquatic bacteria.

The isolated bacteria from naturally infected red swamp crayfish were gram positive cocci, nonmotile, catalase, oxidase and indole negative. From the results of culture, morphological and biochemical tests, the isolated bacteria could be identified as Streptococcus faecium as guided by Hardie, (2001). Also the results agree with those reported by Pourgholam et al. (2010). Our result showed that Streptococcus faecium did not grew on MacConky agar. This result agrees with Ebtsam (2002) and disagrees with El-Bouhy (2002) who reported that St. faecium had variable growth on MacConky agar. The isolates had variable grew at $6.5 \% \mathrm{NaCl}$, these results agree with Torkey et al. (2006) and disagree with Ebtsam (2002). These differences may be due to strain difference.

The results revealed that the isolation rate of $S$. faecium from brain was $17.86 \%$. This result may be explain why Clinical symptoms of streptococcosis are characteristically of the neuro-motor type; erratic swimming, swimming in circles and lack of control of 
the pectoral fins, leaving fish in an erect position. (Abowei and Briyai, 2011).

Regarding to the clinical signs, it was revealed that fish infected with Streptococcus faecium showed darkening of body, detached scales and exophthalmia. These results are agreed with those recorded by Zeid (2004) who mentioned that some signs that may distinct for streptococcal disease, include erratic swimming, darkening of the fish, haemorrhage in the base of the fin and the operculum and pop- eye appearance. The common postmortem lesions observed in the diseased fish were acute septicemia and they revealed congestion of the internal organs. These lesions were in accordance with the finding of El-Bouhy (2002) and Safinaz (2006). This may be due to the haemolytic effect of the exotoxin produced by bacteria. During acute phase, streptococcus infection reach the blood stream of the fish and travel to all the internal organs. This will lead to septicemia and you can therefore expect to see the normal internal signs associated with septicemia, such as haemorrhages and inflammatrion in the eye, spleen and kidney (Rasheed and Plumb, 1984).

The successful induction of the streptococcosis experimentally indicate the potential pathogenicity of streptococcus faecium isolated from red swamp crayfish to Nile tilapia This induction was confirm by (Austin and Mclntosh, 1991). This work raised some questions about the danger of $P$. clarkii to fish cultured and fish farm.

\section{REFERENCES}

Abowei, J.F.N. and Briyai, O.F. (2011): A Review of Some Bacteria Diseases in Africa Culture Fisheries. Asian Journal of Medical Sciences 3(5): 206-217.

Austin, B. and Mcintosh, D. (1991): New bacterial fish pathogens and their implication for fish farming. Reviews in medical microbiology.2: 230-236.

Domenech, A.; Fernandez, J.P.; Pascual, C. and Dominguez, L. (1996): Streptococcsis in cultured turbot, Scophthalmus maximus (L.) associated with streptococcus Parauberis. J. of fish diseases, 19: 33-39.

Ebtsam, S.H. (2002): Studies on streptococcosis in Nile tilapia, Oreochromis niltocius, in Assiut (Upper Egypt). Faculty of Veterinary Medicine of Assiut University. M.V.Sc. Thesis.

Edgerton, B.F.; Evans, L.H.; Stephens, F.J. and Overstreet, R.M. (2002): Review of freshwater crayfish diseases and commensal organisms. Aquaculture. 206: 57-135.

El-Bouhy, A.M. (2002): Studies on streptococcosis in some freshwater fishes in relation to aquatic birds. Ph.D. Thesis, Faculty of Veterinary Medicine Zagazig University.
ElKamel, A.A. and Thune, R.L. (2003): Invasion and replication of photobacterium damselae sub species piscicida in fish cell lines. J. Aquatic Animal Health, 15: 167-174.

Emam, WM. and Khalil, MT. (1995): Pollution dynamics and stock assessment of the newly introduced crayfish (procambarus clarkia) in the river Nile Egypt. Proc. Zool. Soc. A. R. Egypt. 26: 131.

Hardie M. Jeremy (2001): Genus Streptocccus Rosenbach. In: Bergey's manual of systematic bacteriology Vol. 2. (Eds) Peter, H.A. Sneath, Nicholas, S. Mair, M. Elisabeth sharpe, John, G. Holt. Pp. 1043-1071. Williams and Wilkins Company, Baltimore Md., U.S.A.

Hubbert, R.M. (1989): Bacterial Diseases in Warm water. Aquaculture. In: Shilo, M. and S. Sarig, (Eds.), Fish Culture in Warm Water Systems: Problems and Trends. CRC Press, Boca Raton, Florida, pp: 179-194.

Kusuda, R. and Salati, F. (1999): Enterococcus seriolicida and Streptococcus iniae. In fish diseases and disorders, Volume 3: Viral, bacterial and fungal infections. Woo, P.T.K. and Bruno, D.W.(ed.). $\mathrm{CaB}$ international publications, New York. USA. Pp. 303-217.

Masser, MP. and Rouse, DB. (1997): Australian red claw crayfish. SRAC publication No. 244: 1-8.

Melba, G.B.; $M$ cGladdery, S.E.; East, I. and Subasinghe, R.P. (2001): Asia Diagnostic Guide to Aquatic Animal Diseases. FAO. Fisheries technical. Paper 402/ 2.

Newaj-fyzul, A.; Mutani, A.; Ramsubhag, A. and Adesiyum, A. (2008): Prevalence of bacterial pathogens and their anti-microbial resistance in tilapia and other pond water in Trinidad. Zoonoses and public health 55, 4: 206-213.

Pourgholam, R. Mokarami Rostami, A. Saeedi, A.A. Shrifpour, I. Ghoroghi, A. and Pourgholam, $H$. (2010): Assessment of acute effects of Streptococcus faecium on some hematological and histopathological parameters in juveniles rainbow trout (Oncorhynchus mykiss). Iranian scientific fisheries journal. 19 (2): 19-30.

Rasheed, V.M. and Plumb, J.A. (1984): Pathogenicity of a non-haemolytic group B Streptococcus sp. In Gulf Killifish (Fundulus grandis). Aquaculture 37: 97-105.

Romalde, J.L. and Toranzo, A.E. (2002): Molecular approaches for the study and diagnosis of salmonid streptococcosis. In: Molecular Diagnosis of Salmonid Diseases, Cunningham, C.O. (ed.). Kluwer Academic Publ., The Netherlands, pp. 211-223.

Saad EL-deen, A.G. and EL-Nisr, N.A. (2011): Bacteriological and histopathological studies on Streptococcosis in Nile tilapia, Oreochromis niloticus. Assiut Vet. Med. J. 57 (113): 109-129. 
Safinaz, G.M. (2006): Streptococcus faecium as a cause of mortalities among cultured monosextilapia. Assiut Vet. Med. J. 52 (109): 47-60.

Torky, H.A.; Soliman, M.K.; El-Ashram, A.M.M. and El-Refaee, A.M.E. (2006): Studies on Streptococcal infections among freshwater fishes with special reference of its diagnosis by polymerase chain reaction test. $7^{\text {th }}$ international symposium on tilapia in Aquaculture. Veracrz, Mexico.

Zeid, D.M.M. (2004): Studies on streptococcosis among cultured and wild Oreochromis niloticus. M.V. Sci. Thesis, Faculty of Veterinary Medicine Suez Canal University

\section{ضراوة الميكروب السبحى من نوع استربتوكوكاس فيكم المعزول من استاكوزا المياة العذبة على اسماك البلطى النيلى$$
\text { آية جلال سعد الدين }
$$

Email:aya9galal@gmail.com

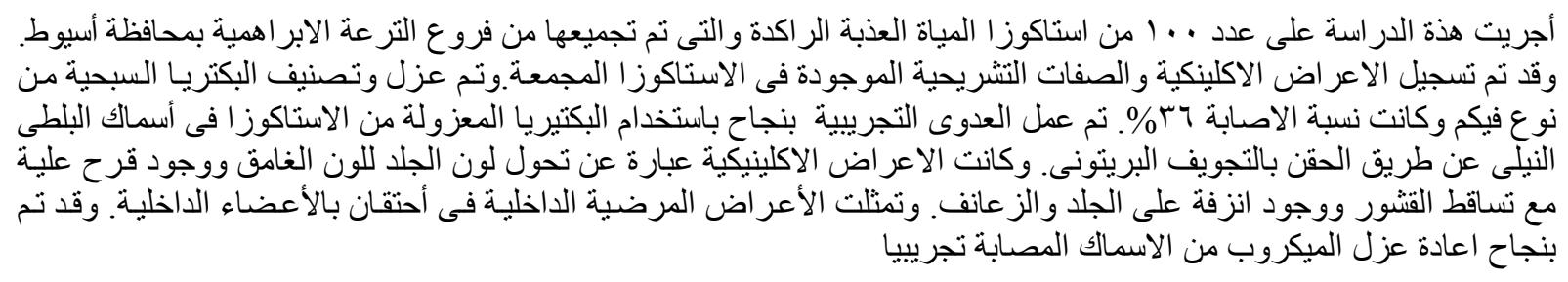

